\title{
Determination of Phenolic Compounds with Antimicrobial Activity of Byrsonima Crassifolia and Inga Edulis Leaves Extracts
}

\section{Determinação de Compostos Fenólicos com Atividade Antimicrobiana dos Extratos de Folhas de Byrsonima Crassifolia e de Inga Edulis}

\author{
Victor Hugo Alves do Nascimento*a; Alessandra Carla Guimarães Sobrinho ${ }^{\mathrm{a}}$; Cintya de Oliveira Souza ${ }^{\mathrm{b}}$; \\ Jesus Nazareno Silva de Souzac; Consuelo Lúcia Sousa ${ }^{\mathrm{a}}$ \\ a'Universidade Federal do Pará, Programa de Pós-Graduação em Ciência e Tecnologia de Alimentos. PA, Brasil. \\ 'Instituto Evandro Chagas. Pará, Brasil. \\ 'Universidade Federal do Pará, Centro de Valorização de Compostos Bioativos da Amazônia. PA, Brasil. \\ *E-mail: victor.itecufpa@gmail.com
}

\begin{abstract}
The aim of this work was to determine the compounds with antimicrobial capacity from crude extracts and leaf fractions of Byrsonima crassifolia and Inga edulis. A solid-liquid extraction was performed using three solvent systems (acetate, methanol and methanol: water). The extracts and fractions were submitted to antimicrobial susceptibility tests for Gram-negative and Gram-positive bacteria by disk diffusion and Minimum Inhibitory Concentration (MIC) methods. A solid phase extraction (SPE) was performed to identify phenolic compounds for pre-concentration and pre-purification of the extracts and fractions that presented antimicrobial potential. The methanolic fraction was able to extract the highest total phenolic content and also presented the largest halos in the disk diffusion test. The minimum inhibitory concentration ranged from 125 to $500 \mu \mathrm{g} / \mathrm{ml} \mathrm{mL}^{-1}$ and from 12.5 to $200 \mu \mathrm{g} / \mathrm{ml} \mathrm{mL}^{-1}$ for Gram-negative and Gram-positive bacteria, respectively. After SPE, the crude extracts and fractions showed inhibition halos against all themicroorganisms tested at a lower concentration when compared to the standardized antibiotics. Gallic acid, ferric acid, myricetin and quercetin showed antimicrobial activity when tested alone. Gallic acid, catechin, epicatechin, ferrulic acid, quercetin, and other 4 major compounds were identified and quantified for Byrsonima crassifolia and 3 compounds for Inga edulis.
\end{abstract}

Keywords: Vegetable Matrices. Antibiotics. Bioactive Compounds. Liquid Chromatography.

\section{Resumo}

O objetivo do presente estudo foi determinar compostos com capacidade antimicrobiana de extratos brutos e frações de folhas de Byrsonima crassifolia e de Inga edulis. Foi realizado uma extração sólido-líquido utilizando três sistemas de solventes (acetato, metanol e metanol:água). Os extratos e frações foram submetidos aos testes de suscetibilidade antimicrobiana para bactérias Gram-negativas e Gram-positivas através dos métodos de disco-difusão e Concentração Inibitória Mínima-CIM. Para identificação dos compostos fenólicos foi realizada Extração em Fase Sólida (SPE), para pré- concentração e pré-purificação dos extratos e frações que apresentaram potencial antimicrobiano. A fração metanólica conseguiu extrair maior conteúdo de fenólicos totais, e apresentou os maiores halos no teste de disco-difusão. A concentração inibitória mínima variou de 125 a $500 \mu \mathrm{gES} \mathrm{mL} L^{-1}$ e de 12,5 a $200 \mu \mathrm{gES} \mathrm{mL} \mathrm{L}^{-1}$ para bactérias Gram-negativas e Gram-positivas, respectivamente. Após SPE, os extratos brutos e frações apresentaram halos de inibição frente a todos os micro-organismos testados em uma concentração menor que a dos antibióticos padronizados. O ácido gálico, ácido ferrúlico, miricetina e quercetina apresentaram atividade antimicrobiana quando testados isoladamente. Foram identificados e quantificados nos extratos brutos e frações ácido gálico, catequina, epicatequina, ácido ferrúlico, quercetina, além de outros 4 compostos majoritários para Byrsonima crassifolia e 3 compostos para Inga edulis.

Palavras-chave: Matrizes Vegetais. Antibióticos. Compostos Bioativos. Cromatografia Líquida.

\section{Introduction}

The appearance of resistant antibiotic microorganisms has increased and caused economic losses in the food industry and global health systems; besides it puts at risk the consumers health due to the adaptive capacity that these microorganisms have acquired over the years with abusive use of antibiotic in the treatment of people and animals. The disorderly and excessive use of antibiotics, in addition to becoming a public health problem, increases the costs of treatments and the patients' prolonged hospitalization, increasing the rates of morbidity and mortality (LOUREIRO et al., 2016; XIONG et al., 2018).

According to Faruque et al. (2019), it is important to find new agents with antimicrobial potential, which is an essential strategy in the objective of reducing disease loads caused by microorganisms. Natural extracts have been used to increase shelf life and improve the food sensory characteristics. These extracts and/or their active principles have shown antibacterial activity, in laboratory studies (YOSSA et al., 2010; IVANOVIC et al., 2012).

The Amazon region stands out for its biodiversity, with vegetable matrices that are used by native communities in the most varied forms, such as teas, infusions, baths, or mixtures of parts of these plants, in the treatment of many infections (RODRIGUES et al., 2014). The study of these Amazonian plants and their bioactive compounds can contribute to the discovery of new antimicrobial compounds, thus helping the 
region technological growth. Initial research has demonstrated the potential of bioactive compounds in relation to the biological activities from Byrsonima crassifolia and Inga edulis leaves (POMPEU et al., 2012; TAUCHEN et al., 2016; RODRIGUES et al., 2018; SOBRINHO et al., 2020).

Thus, the present study aimed at determining the main phenolic compounds responsible for the antimicrobial activity from murucizeiro (Byrsonima crassifolia) and ingazeiro (Inga edulis) leaves.

\section{Material and Methods}

\subsection{Raw material}

The Byrsonima crassifolia and Inga edulis leaf samples were collected in the city of Bonito, State of Pará, Brazil $\left(01^{\circ} 21^{\prime} 45^{\prime}\right.$ S S and $\left.47^{\circ} 18^{\prime} 21^{\prime \prime} \mathrm{W}\right)$. Taxonomic identification was performed by comparing exsiccates deposited in the herbarium database of Emílio Goeldi museum herbarium, which the registration number is 220955 for Byrsonima crassifolia and 220956 for Inga edulis.

\subsection{Strains of microorganisms used}

The microorganisms used were ATCC (American Type Culture Collection) standard strains from the National Institute of Quality Control in Health (INCQS) of the Oswaldo Cruz Foundation (FIOCRUZ). The microorganisms used in this work were Gram-negative bacteria: Salmonella Typhimurium INCQS 00150 (ATCC 14028) and Escherichia coli INCQS 00033 (ATCC 25922); Gram-positive bacteria: Staphylococcus aureus INCQS 00039 (ATCC 6538) and Enterococcus faecalis INCQS 00234 (ATCC 2912).

A confirmation test of the bacterial microbial species and the antibiotics susceptibility profile was carried out (from the previous sensitivity profile data, the antibiotic choices were used as a positive control for each microbial strain), by the automated method using ID cards Vitek 2® ID (bioMérieux), according to the manufacturer's instructions. From the susceptibility profile, an antibiotic, in which the bacterial species was resistant, was chosen as a positive control for the resistance phenotype.

\subsection{Vegetable extracts obtaining}

The leaf samples were sent to the Center of Valorization of Bioactive Compounds of the Amazon-CVACBA (UFPA) and submitted to manual selection, washing with running water, drying in an oven with air circulation $\left(60^{\circ} \mathrm{C}\right.$ for 8 hours $)$ and ground ( $5 \mathrm{~mm}$ particle size). Then, the samples were put into plastic containers and stored $\left( \pm 4^{\circ} \mathrm{C}\right)$, until experiments use.

A solid-liquid extraction process was performed using three sequential solvent systems: ethyl acetate, methanol and methanol and water (1:1 v: v) (POMPEU; SILVA; ROGEZ, 2009). A one-hour double extraction was performed for each solvent at a temperature of $28{ }^{\circ} \mathrm{C}$, at a ratio of 1:6 (mass: volume) of dry grinded leaf for solvent.
The crude extract was obtained by joining equal volumes of the three fractions. All of them were concentrated in rotary evaporator.

\subsection{Total phenolics determination}

The total phenolics content was determined by the Folin-Ciocalteu method, expressed in milligrams of quercetin equivalents per gram of dry extract (mgEQ $\mathrm{gDE}^{-}$ 1) (SINGLETON; ORTHOFER; LAMUELA-RAVENTOS, 1999).

\subsection{Antimicrobial susceptibility testing: Disk diffusion method}

The crude extracts and fractions from vegetable matrices were standardized to a concentration of $200 \mu \mathrm{gEQ} \mathrm{mL}^{-1}$ of dry extract diluted in ultrapure water. The antimicrobial activity was evaluated by agar-diffusion method (CLSI, 2020).

The bacterial suspensions were cultured for 18 hours at $36^{\circ} \mathrm{C}$ in Mueller-Hinton broth. Subsequently a new inoculation was performed under the same conditions but incubated only for 6 hours (for use of the recent inoculum). The concentration of the bacterial suspension was adjusted to a scale of 0.5 McFarland $\left(1.5 \times 10^{8} \mathrm{CFU} \mathrm{mL}^{-1}\right)$ and with the aid of sterile $s w a b$, the bacterial inoculum was evenly distributed on the Mueller-Hinton agar surface. The disks ( $6 \mu \mathrm{g}$ of filter paper prepared in the laboratory) were uniformly distributed on the agar surface, using tweezer, and impregnated with $10 \mu \mathrm{L}$ (2 $\mu \mathrm{gEQ}-$ micrograms of quercetin equivalents) and $20 \mu \mathrm{L}$ (4 $\mu \mathrm{gEQ}$-micrograms of quercetin equivalents) of the extracts and fractions of each plant matrix.

For Gram-negative bacteria, ampicillin $(10 \mu \mathrm{g})$ and Gram-positive vancomycin $(30 \mu \mathrm{g})$ were used as controls for the phenotype. The plates were incubated at $36^{\circ} \mathrm{C}$ for 18-24 hours and the inhibition halos formed were evaluated. Only the extracts and fractions that presented the halos with diameters $\geq 8 \mathrm{~mm}$ were considered with antimicrobial activity (FIGUEIREDO; SÁBER, 2016).

An evaluation of the antimicrobial activity of the total phenolics was performed in an isolated and in a synergy form (mixture), using $20 \mu \mathrm{L}$ ( $2 \mathrm{~g}$ of compound per disk), as well as the analysis by disk diffusion of the crude extracts and fractions of the vegetable matrices, after a cleaning process using Solid Phase Extraction (SPE) cartridges, using $20 \mu \mathrm{L} /$ disk. The total phenolics concentrations after SPE impregnated on disks were: $10 \mu \mathrm{gESS}^{-1}, 12.9 \mu \mathrm{gESS}^{-1}$ and $12.2 \mu \mathrm{g} \mathrm{gES}^{-1}$ per disk of crude extract, methanol fraction and methanol: water fraction, respectively, for Byrsonima crassifolia and $9 \mu \mathrm{g} \mathrm{gES}^{-1}, 12.2$ $\mu \mathrm{g} \mathrm{gES}{ }^{-1}$ and $8 \mu \mathrm{gES}^{-1}$ per disk of crude extract, methanolic fraction and methanol: water fraction, respectively for Inga edulis.

\subsection{Minimum inhibitory concentration determination (MIC)}

The determination of the minimum inhibitory concentration 
was performed by the broth microdilution method, using a 96well U-bottom plate containing $100 \mu \mathrm{L}$ of Mueller-Hinton broth (CLSI, 2020).

Successive dilutions of the crude extracts and fractions from the two vegetables matrices were performed in order to obtain dilutions in the concentrations between 1.56 and 200 $\mu \mathrm{g} \mathrm{mL} \mathrm{m}^{-1}$, for Gram-negative bacteria and between 3.90 and $500 \mu \mathrm{g} \mathrm{mL}^{-1}$, for tests with Gram-positive bacteria. Then, 100 $\mu \mathrm{L}$ of each dilution was added to the corresponding wells. Subsequently, $100 \mu \mathrm{L}$ of the bacterial suspension adjusted to the 0.5 scale of McFarland $\left(1.5 \times 10^{8} \mathrm{CFU} \mathrm{mL}^{-1}\right)$ was added to the wells. The microplates were incubated at $36^{\circ} \mathrm{C}$, for 24 hours, and the analyzes were performed in triplicate.

After the incubation time, $10 \mu \mathrm{L}$ of resazurin $(0.1 \mathrm{mg}$ $\mathrm{mL}^{-1}$ ) was added to the wells for the microbial growth observation, and in the 4 to 6 hour period it was observed if there was staining change. Blue staining indicates absence of microbial growth and red/pink one indicates the presence of viable bacterial cells in growth. Wells were reserved where the test controls were performed: the medium sterility control, the inoculum control, the extract control and the resazurin indicator control. Levels of Minimum Inhibitory Concentration were classified as follows: inactive potential (> $100 \mu \mathrm{g} \mathrm{mL}^{-1}$ ), low potential (between 550 and $100 \mu \mathrm{g} \mathrm{mL}^{-1}$ ), moderate active potential (between 100 and $500 \mu \mathrm{g} \mathrm{mL}^{-1}$ ) and active potential $\left(<100 \mu \mathrm{g} \mathrm{mL}^{-1}\right)$.

\subsection{Total phenolics identification and quantification}

The crude extracts and fractions ( $4 \mu \mathrm{gEQ}$-micrograms of quercetin equivalents) which had positive results in the antimicrobial activity evaluation (halos $\geq 8 \mathrm{~mm}$ ) were submitted to cleaning, using Strata C18-E SPE cartridge (Phenomenex) $55 \mathrm{um}, 200 \mathrm{mg} 3 \mathrm{~mL}^{-1}$, according to Dias, Souza e Rogez (2010). The SPE cartridges were preconditioned with $10 \mathrm{~mL}$ of methanol containing $1 \%$ of formic acid, then 200 $\mu \mathrm{L}$ of the crude extract and fractions were added to $800 \mu \mathrm{L}$ of ultrapure water. Cleaning was performed with $5 \mathrm{~mL}$ of ultrapure water, and the final elution was performed with $100 \%$ methanol. The sample was dried, weighed and resuspended in $5 \mathrm{~mL}$ of $40 \%$ methanol with $1 \%$ of formic acid.

For the chromatographic analyzes, a UHPLC Thermo Scientific (USA) system equipped with a quaternary pump (LPG-3400RS) and automatic injector (WPS-3000SL Analytical) was used, using as detector a diode arrangement system (DAD-3000) (Chromoleon 7.1 SR2), flow cell (Standard Analytical) and Kinetex C18 column 2.6 $\mu \mathrm{m}$, 100x4.6 mm (Phenomenex). $20 \mu \mathrm{L}$ of the sample was injected, filtered on $0.45 \mu \mathrm{m}$ porosity PVDF filters and the mobile phases were ultrapure water with $1 \%$ of formic acid (solution A) and acetonitrile with $1 \%$ of formic acid (solution B). These were prepared and filtered with nylon membranes $(0.22 \mu \mathrm{m}$ porosity) and submitted to ultrasonic bath for 15 minutes. The following gradient was used: $3 \% \mathrm{~B}$ (0 to 13 minutes); 16\% B (18 minutes); 16\% B (24 minutes); 19\% B (24.5 minutes); 22\% B (26 minutes); 36\% B (27 minutes); 36\% B (34 minutes); 90\% B (39 minutes); 90\% B (40 minutes); 3\% B (43 minutes) according to the methodogy of Dias, Souza and Rogez (2010).

The compounds identification and quantification in the matrices were performed by the comparisons of retention times and area formed with the standards used. The choice of the major peaks was also performed, that were not identified by the standards used, which were quantified through the formed area and related to a possible class of phenolic compounds. The results were expressed in $\mathrm{mgEM} \mathrm{gES}^{-1}$ (milligrams of myricetin equivalents per gram of dry extract) to Byrsonima crassifolia and in mgEQ $\mathrm{gDE}^{-1}$ (milligrams of quercetin equivalents per gram of dry extract) to Inga edulis.

\subsection{Statistical analysis}

The results of the means obtained in the antimicrobial activity analysis were submitted to analysis of variance (ANOVA) and Tukey's test at the significance level of 5\% with the aid of the program Statistica ${ }^{\circledR}$ version 7.0.

\section{Results and Discussion}

The Byrsonima crassifolia presented higher total phenolic content than Inga edulis (Table 1). It was observed that the polar, methanol and methanol: water fractions were able to extract higher concentrations of total phenolics. The literature reports that alcoholic extracts present higher levels of total phenolics, with ethanol and methanol as the best extractors compared to less polar and pure solvents (KUMAR et al., 2018; SOBRINHO et al., 2020).

Table 1 - Total phenolics of the crude extract and leaf fractions of muruci (Byrsonima crassifolia) and Ingá (Inga edulis)

\begin{tabular}{|c|c|c|}
\hline \multirow{2}{*}{$\begin{array}{c}\text { Extract/ } \\
\text { Fractions }\end{array}$} & \multicolumn{2}{|c|}{ Total phenolics (mg EQ gDE $^{-1}$ ) } \\
\cline { 2 - 3 } & Byrsonima crassifolia & Inga edulis \\
\hline C.E & $124.39 \pm 4.11$ & $59.49 \pm 2.55$ \\
\hline E.A.F & $43.54 \pm 2.21$ & $35.26 \pm 2.12$ \\
\hline M.F & $341.47 \pm 5.10$ & $183.65 \pm 7.20$ \\
\hline F.M:A & $210.80 \pm 1.56$ & $163.92 \pm 2.88$ \\
\hline
\end{tabular}

C.E $=$ Crude extract. E.A.F $=$ Ethyl acetate fraction. M.F = Methanol fraction. M:W.F = Methanol:water fraction; $\mathrm{mg} \mathrm{EQ} \mathrm{gDE}^{-1}=$ (milligrams of quercetin equivalents per gram of dry extract).

Source: Sobrinho et al. (2020).

The results presented in table 1, were shared with the work of Sobrinho et al. (2020), who used the same samples. The apolar fraction (ethyl acetate) was the one that extracted the least amount of total phenolics. A satisfactory method has not been developed yet for extracting all or a specific class of total phenolics present in vegetable matrices, as the solubility of these varies according to the solvent polarity, degree of polymerization and its interactions with other constituents of the matrix (ANGELO; JORGE, 2007; DUTRA et al., 2016). The literature reports lower values than those found in the present work when studying the total phenolics extraction in methanolic fraction, with values corresponding to $254.7 \mathrm{mg}$ 
GAE.100g-1 DM (milligrams of gallic acid per 100 grams of dry matter), for Byrsonima crassifolia; and $6.4 \mathrm{mg} \mathrm{GAE} . \mathrm{g}^{-1}$ DE (milligrams of gallic acid per grams of dry extract), for methanolic extracts of Inga edulis (SOUZA et al., 2007; GORDON et al., 2011).

In order to evaluate the bacterial growth inhibition, the crude extracts and fractions were standardized at two concentrations: 2 and $4 \mu \mathrm{g}$ EQ/disk. The highest inhibition halos were observed in the disks with the highest concentration $(4 \mu \mathrm{g})$ in impregnated quercetin equivalents, since these values differed statistically $(p<0.5)$ from the disks with lower concentration (Table 2). The methanol fraction presented the highest inhibition halos, followed by the hydrometanic fraction and crude extract, that may be related to higher potential of the bioactive compounds in the respective fractions. The ethyl acetate fraction did not show inhibition halos in the parameters used in this study, because its apolar characteristic extracted total phenolics that did not present inhibition for the tested microorganisms.

Table 2 - Inhibition halos diameter obtained for the crude extract and fractions of Byrsonima crassifolia and Inga edulis

\begin{tabular}{|c|c|c|c|c|c|c|c|c|}
\hline \multirow{10}{*}{ 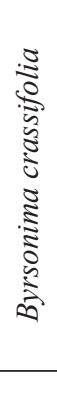 } & \multirow{2}{*}{ Microorganisms } & \multirow{2}{*}{$\begin{array}{c}\mu \mathrm{g} \mathrm{EQ} / \\
\text { disk }\end{array}$} & \multicolumn{4}{|c|}{ Crude extract and fractions/Inhibition halos (mm) } & \multicolumn{2}{|c|}{ Controls (mm) } \\
\hline & & & C.E & E.A.F & M.F & M:W.F & AMP & VAN \\
\hline & \multirow{2}{*}{ S.Typhimurium } & 2 & $6.89 \pm 0.1^{\mathrm{cB}}$ & N.A & $10.95 \pm 0.2^{\mathrm{aB}}$ & $9.33 \pm 0.3^{\mathrm{bB}}$ & \multirow{2}{*}{$18.60 \pm 0.1$} & \\
\hline & & 4 & $9.13 \pm 0.1^{\mathrm{cA}}$ & N.A & $13.02 \pm 0.1^{\mathrm{aA}}$ & $12.00 \pm 0.2^{\mathrm{bA}}$ & & \\
\hline & \multirow{2}{*}{ E.coli } & 2 & $6.00 \pm 0.4 \pm^{\mathrm{cB}}$ & N.A & $10.21 \pm 0.4^{\mathrm{aB}}$ & $8.27 \pm 0.1^{\mathrm{bB}}$ & \multirow{3}{*}{$15.22 \pm 0.1$} & \\
\hline & & 4 & $7.35 \pm 0.2^{\mathrm{cA}}$ & N.A & $14.00 \pm 0.2^{\mathrm{aA}}$ & $11.00 \pm 0.2^{\mathrm{bA}}$ & & \multirow{3}{*}{$17.14 \pm 0.1$} \\
\hline & \multirow{2}{*}{ S.aureus } & 2 & $10.81 \pm 0.2^{\mathrm{bB}}$ & N.A & $12.75 \pm 0.4^{\mathrm{aB}}$ & $7.30 \pm 0.3^{\mathrm{cB}}$ & & \\
\hline & & 4 & $14.55 \pm 0.3^{\mathrm{bA}}$ & N.A & $19.47 \pm 0.2^{\mathrm{aA}}$ & $10.80 \pm 0.2^{\mathrm{cA}}$ & & \\
\hline & \multirow[t]{2}{*}{ E.faecalis } & 2 & $9.10 \pm 0.3^{\mathrm{bB}}$ & N.A & $11.4 \pm 0.3^{\mathrm{aB}}$ & $6.83 \pm 0.4^{\mathrm{cB}}$ & & \multirow{2}{*}{$16.13 \pm 0.1$} \\
\hline & & 4 & $12.00 \pm 0.3^{\mathrm{bB}}$ & N.A & $14.2 \pm 0.4^{\mathrm{aB}}$ & $10.38 \pm 0.3^{\mathrm{cB}}$ & & \\
\hline \multirow{8}{*}{ 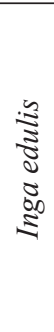 } & S.Typhimurium & 2 & $6.48 \pm 0.1^{\mathrm{cB}}$ & N.A & $10.55 \pm 0.2^{\mathrm{aB}}$ & $8.33 \pm 0.3^{\mathrm{bB}}$ & \multirow{2}{*}{$18.00 \pm 0.1$} & \\
\hline & & 4 & $7.81 \pm 0.1^{\mathrm{cA}}$ & N.A & $14.04 \pm 0.1^{\mathrm{aA}}$ & $10.10 \pm 0.2^{\mathrm{bA}}$ & & \\
\hline & E.coli & 2 & $6.91 \pm 0.2^{\mathrm{cB}}$ & N.A & $10.21 \pm 0.4^{\mathrm{aB}}$ & $9.37 \pm 0.1^{\mathrm{bB}}$ & \multirow{2}{*}{$16.35 \pm 0.1$} & \\
\hline & & 4 & $8.71 \pm 0.4^{\mathrm{cA}}$ & N.A & $14.00 \pm 0.2^{\mathrm{aA}}$ & $11.60 \pm 0.2^{\mathrm{bA}}$ & & \\
\hline & S.aureus & 2 & $6.48 \pm 0.2^{\mathrm{cB}}$ & N.A & $13.00 \pm 0.4^{\mathrm{aB}}$ & $8.60 \pm 0.3^{\text {bB }}$ & & \multirow{2}{*}{$18.11 \pm 0.1$} \\
\hline & & 4 & $10.19 \pm 0.3^{\mathrm{cA}}$ & N.A & $15.77 \pm 0.2^{\mathrm{aA}}$ & $13.00 \pm 0.2^{\mathrm{bA}}$ & & \\
\hline & E.faecalis & 2 & $6.12 \pm 0.2^{\mathrm{cB}}$ & N.A & $9.00 \pm 0.2^{\mathrm{aB}}$ & $7.03 \pm 0.4^{\mathrm{bB}}$ & & \multirow{2}{*}{$17.50 \pm 0.1$} \\
\hline & & 4 & $8.10 \pm 0.3^{\mathrm{cA}}$ & N.A & $11.00 \pm 0.3^{\mathrm{aA}}$ & $9.00 \pm 0.4^{\mathrm{bA}}$ & & \\
\hline
\end{tabular}

Means followed by the same lowercase letter at lines (among fractions) and same capital letter at columns (among concentrations of milligrams of quercetin equivalents per disk) indicate no significant difference to the same specie by the Tukey test ( $\mathrm{p} \leq 0.05)$; Extracts in 2 and 4 micrograms of quercetin equivalents per disk; C.E= Crude extract; E.A.F= Ethyl acetate fraction; M.F= Methanol fraction; M:W.F= Methanol:water fraction; N.A= No antimicrobial activity; $\mathrm{AMP}=$ Ampicillin $(10 \mu \mathrm{g}) ; \mathrm{VAN}=$ Vancomycin $(30 \mu \mathrm{g})$.

Source: Research data.

Vegetable extracts are important sources of antimicrobial agents due to the presence of secondary plant metabolites, especially phenolic compounds. Such compounds have biological properties, and their use in human are more often preferred over synthetic drugs, since they are less harmful to human health (BHATTACHARYA et al., 2016).

In general, satisfactory inhibition halos were found in both matrices, mainly by the use of quercetin equivalent concentrations ( 2 and $4 \mu \mathrm{g}$ ) smaller than the used standards, ampicillin and vancomycin, 10 and $30 \mu \mathrm{g}$ per disk, respectively. This is a broad spectrum of antimicrobial action and considerable action of the bioactive components present in the two matrices. Other studies in leaves of Byrsonima crassilfolia and Inga edulis observed antimicrobial action against strains of Salmonella, Escherichia coli, Enteroccoccus faecalis and Staphylococcus aureus (DUTRA et al., 2016).

The antimicrobial activity can be influenced by several factors, such as chemical composition of the vegetable species, harvest season, part of the plant used in the study, geographic origin and extraction form. In addition, it should be emphasized that the different resistance patterns presented by the microorganisms, their origin (isolation) and characteristics of the bacterial genre in question may influence the inhibitory effect of the tested material (MOURA et al., 2013).

The methanol fraction showed the lowest MIC, followed by the methanol: water fraction and crude extract (Table 3). This may be directly related to the fact that this fraction presented higher content of total phenolics, in the two matrices, which are directly correlated with several biological properties, including antimicrobial activity (ANGELO; JORGE, 2007; SOUZA et al., 2008).

Table 3 - Minimum inhibitory concentration (MIC) values of the crude extracts and fractions of Byrsonima crassifolia and Inga edulis

\begin{tabular}{|l|c|c|c|c|c|}
\hline \multirow{2}{*}{$\begin{array}{l}\text { Vegetable } \\
\text { matrices }\end{array}$} & \multirow{2}{*}{$\begin{array}{l}\text { Extracts/ } \\
\text { fractions }\end{array}$} & \multicolumn{4}{|c|}{ MIC in $\mu \mathrm{gDE}^{\mathrm{mL}} \mathrm{mL}^{-1}$} \\
\cline { 3 - 6 } & & $\begin{array}{c}S . \\
\text { Typhimurium }\end{array}$ & E. coli & $\begin{array}{c}S . \\
\text { aureus }\end{array}$ & $\begin{array}{c}\text { E. } \\
\text { faecalis }\end{array}$ \\
\hline \multirow{3}{*}{$\begin{array}{c}\text { Byrsonima } \\
\text { crassifolia }\end{array}$} & C.E & 100.00 & 100.00 & 500.00 & 500.00 \\
\cline { 2 - 6 } & M.F & 12.5 & 12.5 & 125.00 & 125.00 \\
\cline { 2 - 6 } & M:W.F & 50.00 & 50.00 & 250.00 & 250.00 \\
\hline \multirow{3}{*}{ Inga edulis } & C.E & 200.00 & 200.00 & 500.00 & 500.00 \\
\cline { 2 - 6 } & M.F & 12.5 & 12.5 & 125.00 & 125.00 \\
\cline { 2 - 6 } & M:W.F & 25.00 & 25.00 & 125.00 & 125.00 \\
\hline
\end{tabular}


C.E $=$ Crude extract; E.A.F = Ethyl acetate fraction; M.F= Methanol fraction; $\mathrm{M}: \mathrm{W} . \mathrm{F}=$ Methanol:water fraction. $\mu \mathrm{gDE} \mathrm{mL}^{-1} 1=$ micrograms of dry extract per mililiters. The MIC levels were: $>1000 \mu \mathrm{g} \mathrm{mL}^{-1}$ (inactive); MIC between 500 and $1000 \mu \mathrm{g} \mathrm{mL}^{-1}$ (low); MIC between 100 and $500 \mu \mathrm{g}$ $\mathrm{mL}^{-1}$ (moderate active); $\mathrm{MIC}<100 \mu \mathrm{g} \mathrm{mL}^{-1}$ (active).

Source: Research data.

The methanol and methanol: water fractions in the two matrices showed to be active $(<100 \mu \mathrm{g} \mathrm{mL}-1)$, for the Gram-negative (S. Typimurium and E. coli) microorganisms and moderate active for the Gram-positive (Staphylococcus aureus and Enterococcus faecalis). The crude extracts from the two vegetable matrices showed moderate active potential (100 to $500 \mu \mathrm{g} \mathrm{mL}^{-1}$ ), for all the tested bacteria.

The results demonstrate that the crude extracts present low values for the minimum inhibitory concentration (MIC) in the main strains tested for both plants. Thus, there is a range of these compounds present in crude extracts, as observed by Sobrinho et al. (2020). It is clear that when these are fractioned, the MIC value decreased considerably, mainly for Gramnegative microorganisms ( $S$. Typhimurium and E. coli). This inhibitory effect could be even greater from a purification of key molecules, which have greater activity against microbial strains (KUMAR et al., 2018).

The crude extracts and fractions that presented antimicrobial activity $(\geq 8 \mathrm{~mm}$ ) underwent a cleaning process, by SPE C18 cartridges. The crude extracts and fractions of the two matrices showed halos with antimicrobial activity for all the microorganisms tested (Table 4). After cleaning, the methanol fraction presented the largest halos for both Gramnegative and Gram-positive microorganisms, again.

Table 4 - Inhibition halos diameter obtained by the disk diffusion method for the crude extract and fractions of Byrsonima crassifolia and Inga edulis after prepurification by SPE

\begin{tabular}{|c|c|c|c|c|c|}
\hline \multirow{2}{*}{ Vegetable matrices } & \multicolumn{5}{|c|}{ Inhibition halos (mm) } \\
\hline & Extracts/Fractions $\mu \mathrm{g} \mathrm{DE}^{-1} /$ disk & S. typhimurium & E.coli & S.aureus & E.faecalis \\
\hline \multirow{3}{*}{$\begin{array}{l}\text { Byrsonima } \\
\text { crassifolia }\end{array}$} & C.E $(10.0)$ & $9.00 \pm 0.2$ & $9.20 \pm 0.2$ & $12.00 \pm 0.1$ & $11.12 \pm 0.2$ \\
\hline & M.F(12.9) & $16.00 \pm 0.1$ & $14.50 \pm 0.2$ & $14.75 \pm 0.1$ & $16.01 \pm 0.3$ \\
\hline & M:W.F(12.2) & $12.00 \pm 0.2$ & $12.88 \pm 0.2$ & $12.60 \pm 0.1$ & $12.54 \pm 0.2$ \\
\hline \multirow{3}{*}{ Inga edulis } & C.E(9.0) & $9.23 \pm 0.2$ & $8.88 \pm 0.2$ & $12.02 \pm 0.1$ & $10.00 \pm 0.1$ \\
\hline & M.F(12.2) & $15.56 \pm 0.2$ & $12.89 \pm 0.3$ & $15.89 \pm 0.1$ & $13.95 \pm 0.1$ \\
\hline & M:W.F(8.0) & $12.01 \pm 0.4$ & $11.01 \pm 0.3$ & $13.00 \pm 0.1$ & $12.00 \pm 0.2$ \\
\hline AMP & & $19.11 \pm 0.1$ & $17.00 \pm 0.1$ & & \\
\hline VAN & & & & $17.23 \pm 0.1$ & $15.00 \pm 0.1$ \\
\hline
\end{tabular}

C.E= Crude extract. M.F= Methanol fraction. M:W.F= Methanol:water fraction. AMP $=$ Ampicillin $(10 \mu \mathrm{g})$. VAN $=$ Vancomycin $(30 \mu \mathrm{g})$.

Source: Research data.

The crude extracts and fractions of the two matrices showed a significant inhibitory effect on the tudy bacteria, in concentrations equivalent to ampicillin $(10 \mu \mathrm{g})$ and smaller than vancomycin $(30 \mu \mathrm{g})$, used as control.

More studies must be done to better elucidate the antimicrobial activity of vegetable extracts with more concentrated and purified compounds, for possible use as a natural antibiotic, replacing the synthetic drugs currently, that present less bactericidal effect, due to the resistance that microorganisms have acquired over the years.

The results showed that the gallic acid, ferrulic acid, quercetin and myricetin showed antimicrobial activity against the tested strains of microorganisms, proving their potential when applied isolated (Table 5). The combination of total phenolics also showed antimicrobial activity, showing halos greater than $8 \mathrm{~mm}$, for both Gram-negative and Grampositive microorganisms. The compounds were effective in the formation of inhibitory halos, as they were in a lower concentration $(2 \mu \mathrm{g})$ than the standards that were used as controls, ampicillin $(10 \mu \mathrm{g})$ and vancomycin $(30 \mu \mathrm{g})$. The antimicrobial activity of the total phenolics varies according to the tested microbial species and the molecule structure.

Table 5 - Inhibition halos diameter obtained by the disk diffusion method for isolated and mixture total phenolics

\begin{tabular}{|c|c|c|c|c|}
\hline \multirow{2}{*}{ Total Phenolics Standards } & \multicolumn{4}{|c|}{ Inhibition halos (mm) } \\
\cline { 2 - 5 } & S.typhimurium & E.coli & S.aureus & E.faecalis \\
\hline Gallic acid & $7.0 \pm 0.4$ & $8.0 \pm 0.3$ & $8.0 \pm 0.4$ & $9.0 \pm 0.4$ \\
\hline Ferrulic acid & $10.0 \pm 0.1$ & $10.0 \pm 0.1$ & $12.0 \pm 0.3$ & $10.0 \pm 0.3$ \\
\hline Catechin & N.A & N.A & N.A & N.A \\
\hline Epicatechin & N.A & N.A & N.A & $8.0 \pm 0.2$ \\
\hline Quercetin & $9.0 \pm 0.3$ & $9.0 \pm 0.1$ & $16.0 \pm 0.3$ & $14.0 \pm 0.2$ \\
\hline Myricetin & $12.0 \pm 0.2$ & $12.4 \pm 0.3$ & $14.30 \pm 0.2$ & $13.11 \pm 0.1$ \\
\hline Combination & $10.0 \pm 0.3$ & $11.20 \pm 0.3$ & & \\
\hline AMP & $19.21 \pm 0.1$ & $17.34 \pm 0.1$ & & $17.00 \pm 0.1$ \\
\hline VAN & & & & $15.45 \pm 0.1$ \\
\hline
\end{tabular}

Concentrated standards in $2 \mu \mathrm{g}$ per disk; Combination ${ }^{1}=$ Mixture of all standards; AMP $=$ Ampicilin $(10 \mu g)$. VAN= Vancomycin $(30 \mu g) ; \mathrm{N} . \mathrm{A}=\mathrm{No}$ antimicrobia activity.

Source: Research data. 
Myricetin was the compound with the highest inhibitory capacity, with the largest halos in the bacteria tested, and close to the halos obtained by standard antibiotics when tested against $S$. aureus and E. faecalis. The literature reports that this compound has potent antimicrobial activity, when found in vegetable matrices (NAGA et al., 2014; BHATTACHARYA et al., 2016).
It was noted the presence of catechin, epicatechin, quercetin and ferrulic acid in the crude extracts and fractions, as well as gallic acid in the crude extracts of the two matrices. However, these compounds were present in low concentrations and were not within the limit of the calibration curve, performed for their quantification (Tables 6 and 7).

Table 6 - Total phenolics concentration in the crude extract and fractions of Byrsonima crassifolia

\begin{tabular}{|c|c|c|c|c|}
\hline Extracts and fractions & Phenolic compound & Read Wavelength (nm) & Retention time (min) & $\begin{array}{c}\text { Compounds } \\
\text { quantification ( } \mathrm{mgEM} \\
\left.\mathrm{gDE}^{-1}\right)\end{array}$ \\
\hline \multirow{8}{*}{ Crude extract } & Gallic acid & 280 & 3.20 & n.q \\
\hline & Catechin & 280 & 7.87 & n.q \\
\hline & Epicatechin & 280 & 10.40 & n.q \\
\hline & Ferrulic acid & 280 & 14.21 & n.q \\
\hline & Compound B2 & 350 & 17.58 & $23.00 \pm 0.40$ \\
\hline & Compound B3 & 350 & 18.70 & $23.00 \pm 0.45$ \\
\hline & Compound B1 & 350 & 20.30 & $20.00 \pm 0.35$ \\
\hline & Compound B4 & 350 & 23.00 & $20.00 \pm 0.45$ \\
\hline \multirow{8}{*}{ Methanol:water fraction } & Gallic acid & 280 & n.i & n.q \\
\hline & Catechin & 280 & 7.84 & $1.00 \pm 0.40$ \\
\hline & Epicatechin & 280 & 10.39 & $1.00 \pm 0.35$ \\
\hline & Ferrulic acid & 280 & 14.20 & n.q \\
\hline & Compound B2 & 350 & 17.58 & $39.10 \pm 0.50$ \\
\hline & Compound B3 & 350 & 18.70 & $25.00 \pm 0.45$ \\
\hline & Compound B1 & 350 & 20.30 & $36.90 \pm 0.50$ \\
\hline & Compound B4 & 350 & 23.00 & $23.80 \pm 0.45$ \\
\hline \multirow{10}{*}{ Methanolic fraction } & Quercetin & 350 & 27.41 & n.q \\
\hline & Gallic acid & 280 & n.i & n.q \\
\hline & Catechin & 280 & 7.87 & n.q \\
\hline & Epicatechin & 280 & 10.40 & n.q \\
\hline & Ferrulic acid & 280 & 14.21 & n.q \\
\hline & Compound B2 & 350 & 17.58 & $70.00 \pm 0.35$ \\
\hline & Compound B3 & 350 & 18.70 & $58.00 \pm 0.40$ \\
\hline & Compound B1 & 350 & 20.30 & $81.00 \pm 0.25$ \\
\hline & Compound B4 & 350 & 23.00 & $38.00 \pm 0.40$ \\
\hline & Quercetin & 350 & 27.47 & n.q \\
\hline
\end{tabular}

The standards deviation represent the variation in the concentrations of the analysis in triplicate. $n . i=$ not identified; $n . q=$ not quantified; $\mathrm{nm}=$ nanometers; $\min =$ minutes; $\mathrm{mgEM} \mathrm{gDE}^{-1}=$ milligrams of myricetin per gram of dry extract.

Source: Research data.

Table 7 - Concentration of total phenolics in the crude extract and fractions of Inga edulis

\begin{tabular}{|c|c|c|c|c|}
\hline $\begin{array}{c}\text { Extracts and } \\
\text { Fractions }\end{array}$ & Phenolic Compound & Read Wavelength (nm) & $\begin{array}{c}\text { Retention } \\
\text { Time (min) }\end{array}$ & $\begin{array}{c}\text { Compounds Quantification } \\
\left.\left(\mathrm{mgEQ}_{\mathrm{gDE}}\right)^{-1}\right)\end{array}$ \\
\hline \multirow{8}{*}{ Crude extract } & Gallic acid & 280 & 3.20 & n.q \\
\hline & Catechin & 280 & 7.87 & n.q \\
\hline & Epicatechin & 280 & 10.40 & n.q \\
\hline & Compound I1 & 350 & 13.56 & $7.00 \pm 0.30$ \\
\hline & Compound I2 & 350 & 13.82 & $5.20 \pm 0.50$ \\
\hline & Ferrulic acid & 280 & 14.21 & n.q \\
\hline & Compound I3 & 350 & 17.20 & $5.73 \pm 0.25$ \\
\hline & Quercetin & 350 & 27.47 & $2.00 \pm 0.45$ \\
\hline \multirow{8}{*}{$\begin{array}{l}\text { Methanol: } \\
\text { water fraction }\end{array}$} & Gallic acid & 280 & n.i & n.q \\
\hline & Catechin & 280 & 7.84 & $2.00 \pm 0.40$ \\
\hline & Epicatechin & 280 & 10.39 & $2.00 \pm 0.55$ \\
\hline & Compound I1 & 350 & 13.56 & $10.00 \pm 0.65$ \\
\hline & Compound I2 & 350 & 13.82 & $8.00 \pm 0.50$ \\
\hline & Ferrulic acid & 280 & 14.21 & $1.00 \pm 0.45$ \\
\hline & Compound I3 & 350 & 17.20 & $110.00 \pm 0.70$ \\
\hline & Quercetin & 350 & 27.39 & n.q \\
\hline
\end{tabular}




\begin{tabular}{|c|c|c|c|c|}
\hline \multirow{4}{*}{$\begin{array}{c}\text { Methanolic } \\
\text { fraction }\end{array}$} & Gallic acid & 280 & n.i & n.q \\
\cline { 2 - 5 } & Catechin & 280 & 7.87 & n.q \\
\cline { 2 - 5 } & Epicatechin & 280 & 10.40 & $\mathrm{n} . \mathrm{q}$ \\
\cline { 2 - 5 } & Ferrulic acid & 280 & 14.21 & $79.00 \pm 0.40$ \\
\cline { 2 - 5 } & Compound I1 & 350 & 13.56 & $49.00 \pm 0.50$ \\
\cline { 2 - 5 } & Compound I2 & 350 & 17.20 & $6.40 \pm 0.40$ \\
\cline { 2 - 5 } & Composto I3 & 350 & 27.47 & $\mathrm{n} . \mathrm{q}$ \\
\hline
\end{tabular}

The standards deviation represent the variation in the concentrations of the analysis in triplicate. $n . i=$ not identified; $n . q=$ not quantified; $n m=$ nanometers; $\min =$ minutes; $\mathrm{mgEM} \mathrm{gDE}^{-1}=$ milligrams of myricetin per gram of dry extract.

Source: Research data.

The catechin and epicatechin contents were quantified only in the methanol: water fraction. The major compounds observed in Byrsonima leaves had a retention time of 20.30 minutes (compound B1), 17.58 minutes (compound B2), 18.70 minutes (compound B3) and 23.00 minutes (compound B4), and for Inga edulis times 13.56 minutes (compound I1), 13.82 minutes (compound I2) and 17.2 minutes (compound I3), with absorption peaks in ultraviolet spectra at $350 \mathrm{~nm}$ and $280 \mathrm{~nm}$. According to the spectra presented by these compounds in comparison with the quercetin and myricetin standards and by the literature data, all these compounds belong to the class of flavonols (SOUZA et al., 2007, 2008; DIAS; SOUZA; ROGEZ, 2010). Thus, they were estimated as myricetin and quercetin equivalents because these matrices present higher contents of these compounds.

Studies report concentrations of $0.82 ; 9.67$ and $25.43 \mathrm{mg}$ of compound per gram of dry crude extract, for gallic acid, catechin, epicatechin, respectively, in fractions from Inga edulis extracts and concentrations of 1.98, 13.61, 6.32 and 1.76 $\mathrm{mg} \mathrm{g} \mathrm{DF}-1$ (miligram per gram of dry fraction) for gallic acid, catechin, epicatechin and quercetin, respectively. Presence of procyanidin $\mathrm{B} 1$, procianydin $\mathrm{B} 2$, raminopyranoside quercetin and myricetin were also identified in the exctracts of Inga edulis, and it was observed, as the major compound, the myricetin-3-O- $\alpha$-L-raminopyranoside from Inga edulis

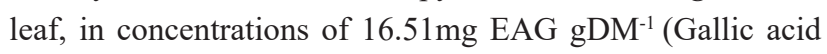
equivalent per gram of dry matter) and concentrations of 18.52 and $26.82 \mathrm{~g} \mathrm{DF}^{-1}$ (miligrams per gram of dry fraction) (SOUZA et al., 2007, 2008; DIAS; SOUZA; ROGEZ, 2010).

For Byrsonima crassifolia, studies have reported the presence of 19 different types of total phenolics, including gallic acid, proanthocyanidins and quercetin derivatives (GORDON et al., 2011).

The variation in the identification and quantification of total phenolics, with the concentrations presented in this study, may have been influenced by several factors, such as the origin of the compound, the amount of secondary metabolites present in the plant, the used extraction method, the time and storage conditions, the pattern used and the presence of interferents (ANGELO; JORGE, 2007; TAUCHEN et al., 2016).

The major compounds present in the two matrices are possibly included in the class of flavonols by the retention time and absorption spectrum, a fact that may be directly related to the antimicrobial activity presented by the matrices, since compounds of this class have been related to innumerable biological properties, including antimicrobial activity (FARUQUE et al. 2019).

\section{Conclusion}

The crude extracts and methanolic and methanol: water fractions presented antimicrobial activity in the two matrices in the disk diffusion test, in concentrations lower than those used in the standard antibiotics, which presented MIC values ranging from active potential to moderate, for the methanolic and methanol fractions: water, and moderate potential for crude extracts. The SPE technique was able to purify/ concentrate higher contents of total phenolics, presenting satisfactory inhibition halos for all the tested microorganisms.

The standards of total phenolics, except for catechin and epicatechin, presented antimicrobial activity for all the tested microorganisms. In the chromatographic analysis, 4 major compounds were identified for Byrsonima crassifolia and 3 for Inga edulis. However, new studies are needed to identify these major compounds and their isolated or synergistic influence on the extracts.

Further research is needed to identify and quantify total phenolics present in these vegetable matrices and their influence on the antimicrobial activity to further elucidate the interference of these compounds used in isolation and in synergism with the vegetable matrix.

\section{Acknowledgments}

Financial assistance from CAPES and CNPq. Support in the accomplishment of the analyzes from Evandro Chagas Institute (IEC) and from the Center of Valorization of Bioactive Compounds of the Amazon (CVACBA).To National Institute of Health Quality Control (INCQS) and to Oswaldo Cruz Foundation (FIOCRUZ), for the strains used in this work.

\section{References}

ANGELO, P.M.; JORGE, N. Phenolic compounds in foods: a brief review. Rev. Inst. Adolfo Lutz, v.66, n.1, p.1-9, 2007.

BHATTACHARYA, S. et al. Hplc of phenolic compounds, antioxidant and antimicrobial activity of bulbs from three Ornithogalum species available in India. Int. J. Pharm. Pharm. Sci., v.8, n.7, p.187-192, 2016.

CLSI - Clinical and Laboratory Standards Institute. Performance Standards for Antimicrobial Susceptibility Testing. CLSI supplement M100. Wayne: CLSI, 2020. 
DIAS, A.L.S; SOUZA, J.N.S; ROGEZ, H. Purification of phenolic compounds from Inga edulis leaves using solid-phase extraction: major compounds quantification and antioxidant capacity evaluation. Quím. Nova, v.33, n.1, p.38-42, 2010. doi:0100-40422010000100008

DUTRA, F.S.G. et al. Atividade antimicrobiana de extratos vegetais frente a bactérias de importância médica. Biol. Saúde, v.20, n.6, p.1-13, 2016. doi: 10.25242/88686202016965

FARUQUE, M.O. et al. Chemical Composition acitivity of congea tomentosa an Ethnomedicinal Plant From Bangladesh. Ind. Crop. Prod., v.141, p.1-10, 2019.

FIGUEIREDO, J.R; SÁBER, M.L. Antimicrobial activity of ethanol extracts of Caesalpinia pulcherrima. REAS, v.8, n.2, p.853-860, 2016. doi: 10.21016/ICRESET.2018.AU14E

GORDON, A. et al. Phenolic Constituents and Antioxidant Capacity of Four Underutilized Fruits from the Amazon Region. J. Agric. Food Chem., v. 59, n.14, p.7688-7699, 2011.

IVANOVIC, J. et al. In vitro control of multiplication of some food-associated bacteria by thyme, rosemary and sage isolates. Food Control., v.25, n.1, p.110-116, 2012. doi: 10.1016/j. foodcont.2011.10.019

KUMAR, R.; SHARMA, S.; DEV, L. Investigation of Total Phenolic, Flavonoid Contents and Antioxidant Activity from Extracts of Azadirachta indica of Bundelkhand Region. Int. J. Life. Sci. Scienti. Res., v.4, n.4, p.1925-1933, 2018. doi:10.21276/ ijlssr.2018.4.4.10

LOUREIRO, R.J. et al. O uso de antibióticos e as resistências bacterianas: breves notas sobre a sua evolução. Rev. Port. Sau. Pub., v.34, n.1, p.77-78, 2016. doi: http://dx.doi.org/10.1016/j. rpsp.2015.11.003

MOURA, F.M.L. et al. Use of plants Caatinga in controlo of pathogens of interest food área: a review. Acta Vet. Bras., v.7, n.2, p.125-136, 2013.

NAGA, V.K.A. et al. Cumulative activity of the p-coumaric acid and syringaldehyde for antimicrobial activity of different microbial strains. Euro J. Exp. Bio., v.4, n.6, p.40-43, 2014.

POMPEU, D.R. et al. Capacidade antioxidante e triagem farmacológica de extratos brutos de folhas de Byrsonima crassifolia e de Inga edulis. Acta Amaz, v.42, n.1, p.165-172,
2012. doi: 10.1590/S0044-59672012000100019

POMPEU, D.; SILVA, E.; ROGEZ, H. Optimisation of the solvent extraction of phenolic antioxidants from fruits of Euterpe oleracea using response surface methodology. Bioresour. Technol., v.100, n.23, p.6076-6082, 2009. doi:10.1016/j.biortech.2009.03.083

RODRIGUES, I.A. et al. Arrabidaea chica hexanic extract induces mitochondrion damage and peptidase inhibition on Leishmania spp. Biomed Res Int, v.2014, p.1-7, 2014. doi: $10.1155 / 2014 / 985171$

RODRIGUES, L.A.N. et al. Fenólicos totais e capacidade antioxidante de extratos de casca, folhas e frutos do Miricizeiro. Tecnol. Ciênc. Agropec., v.12, n.5, p.55-60, 2018.

SINGLETON, V.L.; ORTHOFER, R.; LAMUELA-RAVENTOS, R.M. Analysis of total phenols and other oxidation substrates and antioxidants by means of Folin-Ciocalteu reagent. Method Enzymol, v.299, p.152-178, 1999.

SOBRINHO, A.C.S. et al. Determination of bioactive compounds and scavenging capacity of free radicals in Byrsonima crassifolia and Inga edulis leaf extracts. Braz. J. Develop., v.6, p.3495434969, 2020. doi: 10.34117/bjdv6n6-147

SOUZA, J.N.S. et al. Antioxidant capacity of four polyphenolrich Amazonian plant extracts: a correlation study using chemical and biological in vitro assays. Food Chem., v.106, p.331-339, 2008. doi: 10.1016/j.foodchem.2007.05.011

SOUZA, J.N.S. et al. Identificacion and antioxidante activity of Several flavonoids of Inga Edulis leaves. J. Braz. Chem. Soc., v. 18, n.6, p.1276-1280, 2007.

TAUCHEN, J. et al. Phenolic composition, antioxidant and antiproliferative activities of edible and medicinal plants from the Peruvian Amazon. Rev. Bras. Farmacogn., v.26, n.6, p.728-737, 2016. doi: 10.1016/j.bjp.2016.03.016

YOSSA, N. et al. Antimicrobial activity of essential oils against Escherichia coli O157:H7 in organic soil. Food Control., v.21, n.11, p.1458-1465, 2010. doi: 10.1016/j.foodcont.2010.03.016.

XIONG, W.; SUN, Y.; ZENG, Z. Antimicrobial use and antimicrobial resistance in food animals. Environ Sci. Pollut $R$, v.25, n.2, p.18377-18384, 2018. doi: 10.1007/s11356-018-18522, 25:19. 